\title{
The Relationship between Board Structure and Performance of Firms Listed at the Nairobi Securities Exchange
}

\author{
Dr. Moses Odhiambo Aluoch, PhD \\ Prof. Cyrus Iraya Mwangi, PhD \\ Prof. Erasmus S. Kaijage, PhD \\ Prof. Martin Ogutu, PhD \\ University of Nairobi, Kenya
}

Doi:10.19044/esj.2020.v16n19p337 URL:http://dx.doi.org/10.19044/esj.2020.v16n19p337

\begin{abstract}
This study examines the relationship between board structure and performance of firms listed at the Nairobi Securities Exchange. The study is anchored on agency theory, resource dependency theory, transaction cost theory, political theory and a census approach. A population of the study comprising sixty five companies listed at the Nairobi Securities Exchange between 2002 and 2016 were used. Data was extracted from annual reports of listed firms. This study employed longitudinal descriptive research design to determine the relationship. Panel data regression analysis was conducted using the random effects model. The results revealed that gender diversity and occupational expertise had significant effect on Return on Assets, while board independence and board age had significant effect on Tobin's $Q$ of listed firms in Kenya. On the other hand, board size had an insignificant effect on both Return on Assets and Tobin's Q. The overall effect of board structure on Returns on Assets and Tobin's Q was significant. The study concluded that various board structure mechanisms except board size have significant effect on performance of listed firms in Kenya, and the overall board structure had significant effect on performance of listed firms. The study recommended that management should incorporate board structure mechanisms to enhance performance of firms and regulatory authorities should review the current board structure variables to make them more relevant to improve performance of listed firms in Kenya.
\end{abstract}

Keywords: Board Structure, Board Independence, Gender Diversity, Occupational Expertise, Board Age, Board Size, Returns on Assets and Tobin's Q 


\section{Introduction}

The overall performance of listed firms at the Nairobi Securities Exchange (NSE) has been falling since the introduction of corporate governance policies and guidelines in the year 2002 as measured by Return on Assets (ROA) and Tobin's Q, however the performance of various sectors and individual firms have been varied over the period. The listed firms on the NSE are leaders in various sectors and performance of NSE listed firms is a barometer of Kenyan economic performance. Performance of listed firms are inspired by several factors including corporate governance, financial characters, operational cost, macroeconomic factors, political environment, international trade and global pandemic among others. Board structure is a crucial aspect in the area of corporate governance, since it is treated as a central point of internal governance of the company. Overall behaviour of the company can change with changes of board structure, because every strategic level decision taken by board of a company can impact on entire operations of a firm.

The board structure includes both executive and non-executive directors, foreign directors, women directors, board skills and experience, are occupational expertise, board age and board size. Board inside directors are executive directors while outside directors are non-executive directors. Inside directors for personal reasons may engage risks that are absent for genuine growth opportunities. Directors may take decisions which benefit self-interest. Board diversity includes women and individuals of different races, ethnicities and other minority characteristics broaden a firm's resources. Board diversity brings a bundle of knowledge, experience, ideas and professional contacts, which are used to solve business problems. Board occupational expertise deals with the background, education and experience of board members. Occupational expertise influences the board members in understanding complicated business transactions and gives better decision making. Differences among firms' directors are viewed in terms of their education, background, experience and expertise. Board age is average age of the board members. Average older corporate boards have accumulative experience which might be related with securer sturdier corporate performance. Given modern education younger boards normally have higher and technical knowledge. Younger directors are normally destined to change given dynamics in business environment. They are receptive to adventurous and risk taking a situation which is widely accepted to achieve business developments. Board size is the number of directors instituting the board and it may reflect the complexity of a firm's environment which is inherently challenging; influences board's cohesiveness and ability to oversee corporate governance. Complexities and challenges in a company environment normally defines the 
board size as this further influences board's cohesiveness and capability to supervise corporate governance.

Performance measurement is the procedure of evaluating ability with which reporting firms prosper by economic procurement of resources and the economic placement of resources, in achieving its goals. Performance measure may be based on financial and non-financial information. Performance measure defines ways of evaluating the competence, activities and success of a company. Performance measurement is a way in which corporate managers evaluate their actions in operational, managerial and strategic activities with objectives of the business. It measures if business plans are achieved. Returns on Assets (ROA) and Tobin's Q were employed as profitability and market measures respectively given their rich underlying on concepts. ROA is sales to its total assets and appraises the capability of the firm's directors to create sales by using firm's assets. ROA indicates how directors use scarce resources of the firm to create sales. A higher ROA indicates that the firm is more effective in using scarce resources to create wealth. Tobin's Q takes in consideration many factors such as numbers of share issued, historical of liabilities and total historical value of assets, given the average share price of the company.

Nairobi Securities Exchange (NSE) was established in the year 1954 as the main stock market in Kenya, with deliberate intentions by brokers of shares traded in listed organizations within the confines of societies act. It rebranded its names from Nairobi Stock Exchange to Nairobi Securities Exchange to reflex its wider functions into a full service organization that aids in commercial exchange, clearance and transfer of equities, among other financial assets and traded instruments. NSE is the main stock market in Kenya having different platforms for the listing and multiple securities trading. The market has an obligation to guarantee effective trading in securities and derivatives and enhances economic development. NSE is one of the leading self-listed publicly traded bourses in Africa (NSE, 2016). As at December 2016, there were sixty five listed companies at the NSE. The firms were grouped into twelve different sectors including automobiles and accessories segment, agricultural segment, banking segment, construction and allied segment, commercial services segment, energy and petroleum segment, investment segment, insurance segment, telecommunications and technology segment, investment services segment, manufacturing and allied segment and real estate investment.

Performance of firms listed at the NSE is diverse in terms of profitability and value since the introduction of corporate governance framework by Capital Markets Authority. Some firms posted relatively good returns such as Safaricom Ltd; Equity bank Ltd, Jubulee Insurance Ltd and Barclays bank Ltd among others over the period of the study, however for 
most firms in the banking sector, this has been eroded since the introduction of interest rate cap. On the other hand some have posted dismal performance and posted billions of loses in terms of net profit. Kenya Airways Ltd posted a loss of KES 26,225 million in 2016; Mumias Sugar Company Ltd posted a loss of KES 2,920 million in 2016; Uchumi Supermarkets posted a loss KES 2,671 million in 2016; and East Africa Portland Cement Ltd posted a loss of KES 2,613 million in 2015 among others. Kenya Airways Ltd, Mumias Sugar Company Ltd and Uchumi Supermarkets called for financial bailout from the Kenya government. Some listed firms in the NSE have faced distressing situations following their miserable performance and have been under relentless pressure to deliver quality services and minimum cost, and also to improve their eroded market value. These enormous loses from listed firms have been blamed on various factors including poor board structure mechanisms and implementation.

\section{Litereture Review}

\section{Theoretical Foundation}

Agency Theory was developed by Jensen and Meckling (1976). The theory is grounded on the separation of ownership and relationship between principals and agents. It is based on short term gains where principals delegate decision making authority to their agents; who are to use resources given by the principals to enhance principals' benefits. Agents however, may commit moral hazard by substituting principals' interest with their own (Fama \& Jensen, 1983). Principals normally monitor the activities of agents to ensure that they act on the interest of the firms. Monitoring costs are normally expensive and adversely affect the principals' income (Agrwal \& Knoeber, 1996). This theory is relevant to this study since corporate governance through board structure provides the link between shareholders and corporate management. The board of directors should act in a way to reduce agency conflicts between shareholders and managers. According to principal agency proposition good corporate governance practices motivate and encourage management hence synchronizing shareholders interest and those of management which results to high firm performance.

Resource Dependency theory was developed by Pfeffer and Salancik (1978). The theory deals with the study of how external resources affect the behavior of the organization. The procurement of external resources is an important tenet for both the strategic and tactical management of any company. The theory concentrates on the role of board directors in providing access to resources needed by the firm. The theory emphases on the activities that directors play in finding resources required by the firm through connections to its external environment (Hillman, Canella \& Paetzold, 2000). 
Transaction Cost Theory (TCT) originated from Coarse (1937). When he was investing the reasons companies exists and why they were growing so large. The TCT was later theoretical described and exposed by Williamson (1996). The TCT attempts to view the firm as an organization comprising people with different views and objectives. Transaction costs are incurred in spending time researching, negotiating and agreeing a transaction. The TCT examines how directors would rather enter into agreements for their sources of goods and services as this reduces uncertainty as they have everything they need for the foreseeable future. By doing this the time and expense of sourcing materials is avoided. The unit of analysis in TCT is the transaction and it occurs when dealing with internal and external parties.

Political theory has a very long foundation. However, political theory and corporate governance was initiated by (Pound, 1992). Political theory brings the approach of developing voting support from shareholders, rather by purchasing voting power. Hence having a political influence in corporate governance may direct corporate governance within the organization. Public interest is much reserved as the government participates in corporate decision making, taking into consideration cultural challenges (Pound, 1993). The political model highlights the allocation of corporate power, profits and privileges are determined via the governments' favor. The political model of corporate governance can have an immense influence on governance developments. Over the last decades, the government of a country has been seen to have a strong political influence on firms. As a result, there is an entrance of politics into the governance structure or firms' mechanism (Hawley \& Williams, 1996).

\section{Empirical Review}

\section{Board Independence and Firm Performance}

Board independence manifests from the number of executives and non-executive members of the board and their roles. Executive directors are those obligated to manage the company. According to stewardship theorists executive boards should have depth of knowledge, access to current operating information, technical expertise and commitment to the firm, potentially having a positive impact on firm performance. A non-executive director is one member of a company board, but he or she doesn't involve in the works of management team. Board independence in Kenya and other emerging economies nations under common law is interesting for two main reasons. First listed firms in Kenya and emerging nations under common law are featured concentration of ownership. Although these owners are appointed as non-executive directors to achieve board independence, there is very little to do with monitoring management. Second the idea of board independence is quite unfamiliar for emerging economies like Kenya following Anglo- 
American corporate governance model. Corporate boards in these countries are one-tier, without supervisory board, where the executive and nonexecutive directors' work together in one organisational layer (Rashid, 2018). In Kenya the code of corporate governance practices for issuers of security to the public principle four states that the board shall have policies and procedures in place to ensure independence of its members (CMA, 2015).

Almontaser and Faudziah (2018) examined the relationship between the internal corporate governance mechanism related to the board of directors' characteristics namely (board independence and frequency of board meetings) and firm performance in Jordanian listed firms. The study used Crosssectional data for the year 2013, with a sample of 64 industrial firms listed in the Amman Stock Exchange. Firm performance was measured by ROA as an accounting based performance measure. The study used multiple linear regression analysis and found that board independence is significantly and positively related to ROA.

Maria, Jennifer and Isabel (2018) examined the relationship between board independence and corporate performance, measured by technical efficiency. The research questions were examined using an international sample of 2185 firms from 2006 to 2015, applying truncated regression models for panel data and employing data envelopment analysis to examine efficiency as a measure of performance and found that board independence increases the firm's technical efficiency. Rashid (2018) examined whether board independence influences firms' economic performance among listed firms in Bangladesh. The study used data from 135 listed firms on Dhaka Stock Exchange and both accounting and market performance measures. The study further used simultaneous equation approach to control the potential endogeniety problem and found that there is no significant relationship between board independence and firm economic performance.

Hamdan and Al Mubarak (2017) explored the effect of board independence on firm's performance from the Stewardship theory perspective. The study used panel data of 162 firms listed in Bahrain Bourse and Saudi Stock Exchange during the period of 2013-2015. The study also used fixedeffect approach and two-stage least squares (2SLS) in order to overcome the endogeneity which exists in such relations and found an inverse effect of board independence on firm performance as measured by ROA and ROE. This study is to examine the relationship between board independence and performance of listed firms in Kenya as measured by ROA and Tobin's Q from 2002 to 2016.

\section{Board Diversity and Firm Performance}

Board diversity includes women and individuals of different races, ethnicities and other minority characteristics broaden a firm's resources. 
Board diversity brings a bundle of knowledge, experience, ideas and professional contacts, which are used to solve business problems. The CMA code of corporate governance practices for issuers of security to the public has not specified the proportion of female directors in the board. According to Aluoch et al. (2019) telecommunication sector had an average of $40 \%$ of female directors in their boards; while banking sector, commercial and services sector; energy and petroleum sector, insurance sector and investment services sector had an average of $20 \%$ of female directors in their boards. Automobile sector had none female directors in their boards, while agricultural sector, construction and allied, investment firms sector and real estate sector had less than $15 \%$ of female directors.

Geeta, D., Narendar V. R., Neha, M., Frank, S. and Debasis, P. (2020) investigated if gender diversity on boards is an effective driver of financial performance both in Singapore and India. Singapore having a soft law approach, while India has mandatory requirements. The study examined comparability between the listed firms of the two countries and found that the gender diversity has a positive and significant effect on the financial performance of the firms of both countries. Mumba (2017) examined the relationship between board gender diversity and financial performance of firms listed on the Lusaka Stock Exchange in Zambia. The study used a panel data analysis approach and cross sectional data for all listed companies for the period 2006 to 2016. The study employed regression analysis as estimation technique to investigate the relationship between board gender diversity (surrogated by the number and proportion of females on the board of directors) and the three financial performance proxies (Return on assets (ROA), Return on equity (ROE) and Leverage). The study found that board gender diversity positively affected firm performance and it explained 5\%,6\% and $9 \%$ of the changes in ROA, ROE and leverage respectively.

Aqil, Qazi and Ntim (2019) investigated the impact of board diversity and quality audit on financial performance by analysing listed firms in Pakistan. Board diversity is investigated in terms of nationality diversity and gender diversity. Audit is studied in domain of quality audit and audit cost. The study sample companies from different sectors in Pakistan Stock Exchange (PSE) 100 Index with representation and highest market capitalization. Panel data set was collected with time span from 2008 to 2017. The study used panel regression analysis and found that that presence of female board members enhance firm performance while a high number of female members in boards was not related to firm financial performance. Nationality diversity is negatively associated with firm financial performance and was mostly due to differences in cross-cultural perceptions and communication barriers. 
Ramzi, Aymen and Faten (2019) investigated the relationship between board gender diversity and firm performance under the enabling and voluntary institutional settings in France. The study used Quantile difference-indifferences and dose-response function estimations and found that comply-or explain recommendation by the French code is likely to decrease performance for poorly performing firms. However, firm performance increases after the enabling date in high-performing firms. The results of the dose-response functions show that accounting performance reaches a threshold of $40 \%$ of women on boards, which coincides with the French law requirements in 2017.

\section{Board Occupational Expertise and Firm Performance}

Board occupational expertise deals with the background, education, profession and experience of board members. Occupational expertise influences the board members in understanding complicated business transactions and gives better decision making. Differences among firms' directors are viewed in terms of their education, background, experience and expertise. Board occupational expertise has significant effect on performance of firms (Omware, Atheru, \& Jagongo, 2020). The CMA code of corporate governance practices for issuers of security to the public principle seven states that all board members shall receive induction on joining the board and shall update their skills and knowledge at regular intervals, while principle eight states that the board shall undertake an annual evaluation of its firm performance, the performance of the chairperson, their committees' individual members, the chief executive officer and company secretary. Board occupational expertise is important internal mechanism corporate governance for listed firms in Kenya (CMA, 2015). For directors' occupational expertise, we used an index of knowledge, experience, education, profession and skills of directors.

Harjoto, Laksmana and Yang (2019) examined the relationship between the nationality and educational background diversity of directors serving on corporate boards and the firms' corporate social performance (CSP). The study measured nationality diversity by directors' national citizenship and educational background diversity by countries from which they earned their undergraduate and post undergraduate degrees; and CSP using the MSCI ESG ratings. The study used both univariate and multivariate analyses to empirically test the hypotheses and found that board nationality diversity and educational background diversity are positively associated with CSP. This study uses index of directors' expertise for all firms listed in Kenya from 2002 to 2016.

Saidu (2019) examined the impact of the chief executive officer's (CEO) ownership, education and origin on firm performance. The study used balanced panel data for 6 years from 2011 to 2016 to run ordinary least square 
regression and from a sample of firms in the financial sector listed on the Nigerian Stock Exchange. The findings indicate that CEO education improves profitability. Similarly, stock performance gets improved when the CEO has prior experience of the firm before being appointed as the chief executive officer. The study concentrated in one sector of the economy, this study however considered all sectors of the market. Swarnodeep and Aurelie (2019) examined the resource provision role of the board of directors in ensuring substantive corporate sustainability practices, specially the presence of nonexecutive directors with previous experience in environmental issuesEEDs - and network connections of EEDs, using greenhouse gas (GHG) emissions data from FTSE 350 firms, as a measure of environmental performance, and found that the presence of EEDs on the board is associated with lower GHG emissions, further firms with better-networked EEDs have better environmental performance.

Arumona, Erin, Onmonya and Omotayo (2019) examined the relationship between board financial education and firm performance of companies operating in the healthcare sector in Nigeria. The study investigated six (6) listed firms for the period from 2011 to 2017 and used ROA as a measure of firm performance. The study adopted fixed effect model of the multiple regression analysis in testing the hypotheses and found that all the explanatory variables have a positive and significant relationship with firm performance. Kamau, Vincent and Aosa (2018) studied corporate governance and performance of financial institutions in Kenya and found no statistically significant relationship between diversity in age, educational level, board experience, technical expertise and gender to firm performance.

\section{Board Age and Firm Performance}

Board age is average age of the board members. Average older corporate boards have accumulative experience which might be related with securer sturdier corporate performance. Given modern education younger boards normally have higher and technical knowledge. Younger directors are normally destined to change given dynamics in business environment. They are receptive to adventurous and risk taking a situation which is widely accepted to achieve business developments. The CMA code of corporate governance practices for issuers of security to the public principle five states that there shall be an age limit for the board members-an age limit of seventy years is recommended which is similar to Denmark and many other countries (Rose, 2007; CMA, 2015).

Carroll (2018) examined how director age influences corporate performance according to Equilar research and found that though older directors generally have more executive and board experience, there is concern that a lack of board refreshment and age diversity can stultify 
companies and result in subpar performance, and on the flipside, that younger executives may be able to bring unique skills to the boardroom to help navigate a fast-changing corporate environment. In addition to actively seeking younger directors, some companies have instituted mandatory retirement ages or term limits as a way to promote regular board refreshment and avoid any of the negative connotations surrounding stale, aging boards. a majority of companies with retirement mandates say that no director can be re-elected to the board after reaching either the age of 72 or 75 . However according to new Equilar research on 500 largest U.S. companies by revenue having younger directors on boards may not necessarily result in better company performance.

Nisar, Amjad and Amna (2018) analysed the effect of boardroom diversity on firm performance in terms of Return on Assets and Return on Capital Employed. The study focused on board diversity, gender diversity, age of the board members, and share of independent directors and executives and found that gender and age had no significant effect on firm performance, whereas, increasing shares of independent directors and executives had a positive influence on firm performance. On the other hand, CEO duality and audit process reduced the financial performance of firms. Nermeen, Ahmed \& Moataz (2017) examined the relationship between board diversity and firm performance in small- and medium-sized enterprises (SMEs) in the U.K. the study investigated the role of gender and age as two dimensions of diversity, using a large sample of SMEs (34,798 firms) located in the U.K. and focusing on the period from 2005 to 2013 and found significant negative association between each of gender diversity and age diversity, and firm performance.

Akisimire, Masoud, Baisi and Orobia (2016) studied board member age diversity and financial performance of manufacturing firms in Uganda. The study used a cross section survey research design using 78 manufacturing firms in Uganda. Data was analysed using descriptive statistics, chi-square analysis and point bi-serial correlation. The results showed that majority of the boards had members with an average age of 35-44years, followed by 25-34 years and majorly of young board members registered low performance, compared to the boards comprising majorly of older members meaning. The results indicated further that board member age diversity is significantly associated with financial performance of manufacturing firms.

\section{Board Size and Firm Performance}

Board size is the number of directors instituting the board and it may reflect the complexity of a firm's environment which is inherently challenging; influences board's cohesiveness and ability to oversee corporate governance (Jensen, 1993). Complexities and challenges in a company environment normally defines the board size as this further influences board's 
cohesiveness and capability to supervise corporate governance (Sanders \& Carpenter, 1998). Smaller boards are preferred on their effectiveness in monitoring the activities of managers than larger boards. Large board size often display dysfunctional characteristics, it hinders the ability to reach a compromise; less involved in long term decision and is difficult to make long term changes (Khanchel, 2007). The CMA code of corporate governance practices for issuers of security to the public has not specified the expected number of the board. The average number of board members for listed firms in Kenya is between 6 and 10. With firms in agricultural sector having an average of six members compared to an average of ten members in Banking , Insurance Sector, Manufacturing Sector and Telecommunication Sector (Aluoch, Iraya, Kaijage \& Ogutu, 2019).

Danoshana and Ravivathani (2019) studied the impact of the corporate governance on firm performance: A study on financial institutions in Sri Lanka. The study used board size, meeting frequency and audit committee as variables to measure the corporate governance and Return on equity and Return on assets measures of performance of the firms. Twenty five listed financial institutions were selected as sample size for the sample period of 2008-2012. The data was collected from secondary sources. According to the regression analysis, variables of corporate governance significantly, impact on firm's performance, board size and audit committee size had positive impact on, firm's performance, while meeting frequency had negatively impact on firm's performance. The study used a few corporate governance variables, the type research designed and research analysis was not elaborated. This study included more variables for board structure and for a long period to determine the relationship between board structure and firm performance.

Ilhan, Ekrem, Geoffrey, Mehmet and Selim (2019) studied the relationship between context, internal corporate governance and firm performance, looking at the case of Turkey, an exemplar of family capitalism. The study found that more concentrated ownership, often in the hands of families, creates better performance, larger boards and foreign ownership stakes seem to have a positive performance impact, Increase in crossownership does not influence market performance but is negatively associated with accounting performance, and that a higher proportion of family board membership has no discernable effect on firm performance. The findings provide further insights on the relationship between the type of institutions encountered in many emerging markets, internal corporate governance configurations and firm performance. The study was based on family effect on corporate governance and firm performance. This study is based on wide concepts of board structure and firm performance for all listed firms in Kenya.

Rekha and Husam-Aldin (2017) studied the relationship between corporate governance and firm performance: Evidence from Gulf Cooperation 
Council (GCC) countries. This study examines the impact of internal mechanisms of corporate governance (CG) on firm performance (FP) in the GCC countries. The study uses firm level panel data set of 349 financial and non-financial companies listed in the stock exchanges of the GCC countries for the period 2005-2012. The study developed an empirical model based on thirteen testable research hypotheses and used Generalized Least Squares (GLS) method to estimate the model parameters and found that governance variables such as government shareholdings, audit type, board size, corporate social responsibility and leverage significantly affect the FP in majority of the countries in the GCC. The results gave rise to certain regulatory and managerial implications, all of which, calls for more concerted efforts in strategically implementing prudent governance solutions in order to future proof GCC business. The study had wide scope on both performance and regulations. This study concentrates more on board structure and performance of listed firms in Kenya.

\section{Board Structure and Financial Performance}

Corporate governance board structure internal mechanisms include: board composition, board diversity, board occupational expertise and education, board age and board size. Kobuthi, K'Obonyo and Ogutu (2018) established effect of corporate governance on performance of firms listed on the Nairobi Securities Exchange (NSE). They developed a corporate governance index as a proxy for corporate governance based on the seven attributes of the recently revised Capital Markets Authority (CMA) code of corporate governance practices for public listed companies in Kenya. The guidelines cover board operations and control, rights of shareholders, stakeholder relations, ethics and social responsibilities, accountability, risk management and internal audit, transparency and disclosure and supervision and enforcement. They used survey questionnaire as a tool of data collection and was distributed to 56 CEOs and corporation secretaries with a response rate of $87.5 \%$. Annual reports for 2015 were used to compute the CGI score for the different organizations. The study found a statistically significant relationship between corporate governance and non-financial performance of firms listed on the Nairobi Securities Exchange confirming that organizations can enhance their performance by implementing good corporate governance, specifically those attributes of good corporate governance that matter. The study was cross-sectional. This study is longitudinal from 2002 to 2016 but also based at the Nairobi Securities Exchange.

Jordi, Rafael and Juan (2018) studied how corporate governance and ownership structure relate to the financial performance of firms. The study estimated relationship using fsQCA and complementary linear and non-linear multiple regression analysis, The panel data used in this study covered 1207 
companies from 59 countries across 19 sectors for the period 2013 to 2015 and found that the multiple empirical techniques employed in this study offer a broader approach to the empirical analysis of financial performance and aids understanding of the role of corporate governance and ownership in the financial performance of firms. However did not names countries under study and the relationship between corporate governance and financial performance, board structure mechanisms are not clearly indicated and the study period is short. This study determines relationship between board structure and performance of firms listed at the Nairobi securities Exchange from the year 2002 to the year 2016.

Suganya and Kengatharama (2017) investigated the relationship between board structure and financial performance of listed finance companies in Sri Lanka. Data were gathered from the financial statements of randomly selected 20 finance companies which are listed on CSE under Bank, Finance and Insurance Sector for the period of 2011-2015. Financial performance was measured by return on assets (ROA). Board size, female board members, CEO duality, and non-executive directors were considered as the parameters of board structure. Data analysis was performed using Pooled OLS and found that board size and non-executive directors had significant relationship with ROA. Besides, female board and CEO duality were not significantly related to ROA. The study used one measure for financial performance, concentrated in one sector of the market and was for a short period of time. This study used two measures of performance and for a long period of 2002-2016 and targeted all sectors of listed firms in Kenya.

\section{Firm Performance}

Performance measurement is the procedure of evaluating ability with which reporting firms prospers by economic procurement of resources and the economic placement of resources, in achieving its goals. Performance measure may be based on financial and non-financial information. Performance measure defines ways of evaluating the competence, activities and success of a company. Performance measurement is a way in which corporate managers evaluate their actions in operational, managerial and strategic activities with objectives of the business. It measures if business plans are achieved (Murby \& Gould, 2005; Nelly, Gregory \& Platts, 2005).

Returns on Assets (ROA) and Tobin's Q were employed as profitability and market measures respectively given their rich underlying on concepts. ROA is sales to its total assets and appraises the capability of the firm's directors to create sales by using firm's assets. ROA indicates how directors use scarce resources of the firm to create sales. A higher ROA indicates that the firm is more effective in using scarce resources to create wealth. Tobin's Q takes in consideration many factors such as numbers of 
share issued, historical of liabilities and total historical value of assets, given the average share price of the company (Khrawish, 2011; Saseela, 2018).

\section{Research Methodology}

This study was based on positivism philosophy since the study involved construction of hypothesis based on empirical and theoretical literature. These were then tested using statistical analysis of quantitative data. Positivism relies more on quantitative measurement that involves testing the hypothesis. This study employed longitudinal descriptive research design to determine relationships amongst independent, intervening, moderating and dependent variables. A longitudinal research design involves repeated observations of the same variables over long periods of time without external influence being applied. The design allowed the researcher to distinguish between short and long-term phenomena, such as performance of firms. This study used a census approach and a target population of the study comprised of all companies listed at the NSE from the year 2002 to 2016. The sixty five (65) companies were screened against various factors which included availability of data for the period under review and the integrity of data.

The data was extracted from published annual reports of listed firms filed with CMA Kenya. Board independence, is proportion of non-executive directors; board gender diversity, number of female and foreign directors on board; board occupational expertise, composite of education, profession and experience of individual board members; board age, average age of board and board size; and board size, total number of directors on the board. ROA was determined as net earnings divided by total assets and Tobin's Q, equity multiplied by share price plus book value of liability divided by book value of assets.

This study followed earlier studies to control for firms-specific effect using control variables. Three variables were used to control for the firm-level effect on the regression result. The study used investment, leverage and liquidity as control variables. Investments was measured in terms of total long term assets divided by total assets, leverage was measured in terms of total debt divided by total assets and liquidity in terms of working capital divided by total assets.

\section{Regression Models}

In this study, it was necessary to ensure no violation of the assumptions of the Classical Linear Regression Model (CLRM) before using the simple linear regression models. The following diagnostic tests were thus necessary: autocorrelation, stationarity, multicollinearity, and heteroscedasticity. This study used descriptive analyses and panel data regression in analysing the 
relationship between corporate governance and firm performance of listed companies at the NSE.

The simple regression models were used to test hypotheses one to six: relationship between board structure variables and performance of firms (FP). $\boldsymbol{H}_{01}$ - Board independence does not significantly affect performance of firms listed at the Nairobi Securities Exchange

The following research hypothesis was tested using the following empirical conceptual model: $\mathrm{FP}_{\mathrm{it}}=\beta_{0}+\beta_{1} \mathrm{BI}_{\mathrm{it}}+\mathrm{ci}+\dot{\varepsilon}_{\mathrm{it}} \ldots \ldots \ldots \ldots \ldots \ldots \ldots \ldots \ldots \ldots \ldots . . . \ldots \ldots$ Equation 1. $\boldsymbol{H}_{02}$ - Board gender diversity does not significantly affect performance of firms listed at the Nairobi Securities Exchange

The following research hypothesis was tested using the following empirical conceptual model: $\mathrm{FP}_{\mathrm{it}}=\beta_{0}+\mathrm{BD}_{\mathrm{it}}+\mathrm{ci}+\dot{\varepsilon}_{\mathrm{it}} \ldots \ldots \ldots \ldots \ldots \ldots \ldots \ldots \ldots \ldots \ldots . . . \ldots \ldots$ Equation 2. $\boldsymbol{H}_{03}$ - Board occupational expertise does not significantly affect performance of firms listed at the Nairobi Securities Exchange

The following research hypothesis was tested using the following empirical conceptual model: $\mathrm{FP}_{\mathrm{it}}=\beta_{0}+\beta_{1} \mathrm{BE}_{\mathrm{it}}+\mathrm{ci}+\dot{\varepsilon}_{\mathrm{it}}$. Equation 3. $\boldsymbol{H}_{04}$ - Board age not significantly affect performance of firms listed at the Nairobi Securities Exchange

The following research hypothesis was tested using the following empirical conceptual model: $\mathrm{FP}_{\mathrm{it}}=\beta_{0}+\beta_{1} \mathrm{BA}_{\mathrm{it}}+\mathrm{ci}+\dot{\varepsilon}_{\mathrm{it}} \ldots \ldots \ldots \ldots \ldots \ldots \ldots \ldots \ldots \ldots \ldots . . . \ldots \ldots$ Equation 4. $\boldsymbol{H}_{05}$ - Board size does not significantly affect performance of firms listed at the

Nairobi Securities Exchange

The following research hypothesis was tested using the following empirical

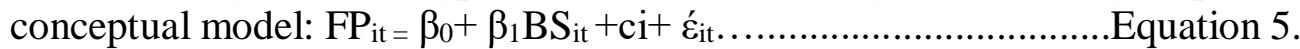
$\boldsymbol{H}_{06}$ - Board structure does not significantly affect performance of firms listed at the Nairobi Securities Exchange

The following research hypothesis was tested using the following empirical conceptual model: $\mathrm{FP}_{\mathrm{it}}=\beta_{0}+\beta_{1} \mathrm{BI}_{\mathrm{it}}+\beta_{1} \mathrm{BD}_{\mathrm{it}}+\beta_{1} \mathrm{BE}_{\mathrm{it}}+\beta_{1} \mathrm{BA}_{\mathrm{it}}+\beta_{1} \mathrm{BS}_{\mathrm{it}}+\mathrm{ci}+$

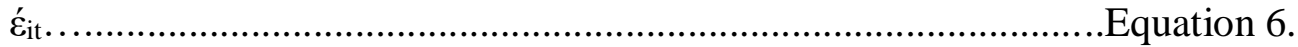

Where: $\mathrm{FP}=$ Firm Performance $; \mathrm{BI}_{\mathrm{it}}=$ Board Independence $; \mathrm{BD}_{\mathrm{it}}=$ Board Diversity; $\mathrm{BE}_{\mathrm{it}}=$ Board Expertise $; \mathrm{BA}_{\mathrm{it}}=$ Board Age; $\mathrm{BS}_{\mathrm{it}}=$ Board Size; $\beta_{0}=$ Constant; $\beta_{1}=$ Regression Coefficients;

$\dot{\varepsilon}_{\mathrm{it}}=$ Error Term . The study's null hypothesis was rejected when calculated pvalues exceeded 0.05 significance level adopted by the study.

\section{Results and Discussions}

Both descriptive and inferential statistics were used to test the relationship between study variables. The study adopted random effect regression analysis to test hypothesis. 


\section{Descriptive Analysis}

Table 1: Descriptive Statistics of Study Variables

\begin{tabular}{|c|c|c|c|c|c|c|r|}
\hline Variable & Indicators & Minimum & Maximum & Mean & Standard Dev. & Skewness & Kurtosis \\
\hline \multirow{4}{*}{$\begin{array}{c}\text { Board } \\
\text { Structure }\end{array}$} & Executive Director & 0 & 5 & 1.66 & 0.858 & 0.978 & 0.648 \\
\cline { 2 - 8 } & $\begin{array}{c}\text { Non-Executive } \\
\text { Director }\end{array}$ & 1 & 15 & 6.6 & 2.604 & 0.156 & 0.282 \\
\cline { 2 - 8 } & Foreign Director & 0 & 9 & 2.17 & 2.003 & 0.767 & -0.17 \\
\cline { 2 - 8 } & Women Director & 0 & 6 & 1.13 & 1.232 & 0.907 & 0.034 \\
\cline { 2 - 8 } & $\begin{array}{c}\text { Occupational } \\
\text { Expertise }\end{array}$ & 1 & 15 & 5.97 & 2.059 & 0.486 & 0.914 \\
\cline { 2 - 8 } & Board Age & 37 & 74 & 55.09 & 4.843 & 0.361 & 1.387 \\
\cline { 2 - 8 } & Board Size & 2 & 16 & 8.24 & 2.491 & 0.068 & -0.054 \\
\hline $\begin{array}{c}\text { Performance } \\
\text { of Firms }\end{array}$ & ROA & -1.382 & 1.798 & 0.14883 & 0.235928 & -0.03 & 8.49 \\
\cline { 2 - 8 } & Tobin's Q & -1.7528 & 6.7098 & 1.390516 & 0.938131 & 2.148 & 5.377 \\
\hline
\end{tabular}

The results showed that listed firms in Kenya had varying board structures. For instance, some firms had a high number of executive directors than others. This was shown by the maximum value of 5 executive directors. However, majority of the firms had an average of 2 executive directors, while other had none as shown by the minimum value of 0 . The finding also showed that non-executive directors were more compared to executive directors. This is shown by the mean of non-executive director being 6 , with the maximum being 15. The standard deviation of 2.604 implied that the variation in nonexecutive directors across listed firms was large. The study also showed that directors in listed firms in Kenya had adequate occupational expertise as shown by mean of 5 years of experience. The minimum age of the board members was 37 years, the maximum age was 74 years and the average age was of 55 years. The firm with the leanest board size had 2 members, while that with the largest board size had 16. The mean board size was 8 members. These findings showed that listed firms in Kenya had varying board structures. The finding in Table 1 indicated that listed firms performed differently during the study period, with some firms recording high performance while others recording very poor performance.

\section{Trends Analysis of the Study Variables}

This section provides the presentations and discussions of trend analysis results. The section enables the researcher to understand the changes in indicators of corporate governance, financial characteristics, macroeconomic variables and indicators of performance for the listed firms in Kenya.

\section{Trends Analysis of the Board Independence}

The study computed board independence by computing a fraction of non-executive directors out of the total board size. The yearly mean for board 
independence for all the listed firms was computed and the resulting data used to draw the trend.

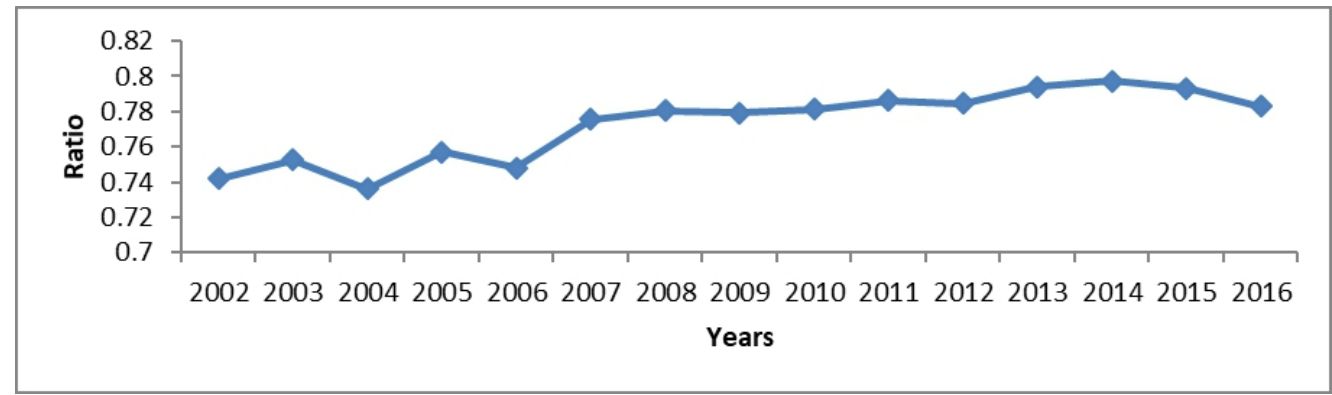

Figure 1: Trend Analysis of Board Independence

The finding presented in figure 1 showed that board independence of listed firms in Kenya tremendously increased between the years of 2006 and 2014. This implied that more non-executive directors have been added to the board of listed firms. The increase in non-executive directors is an indication of the need to protect the shareholders and investors from loses that may arise due to conflict of interest within the o board.

\section{Trends Analysis of the Board Gender Diversity}

The study further sought to analyze the board gender diversity of listed firms in Kenya. Similarly the study computed gender diversity by dividing number of female board members by the board size.

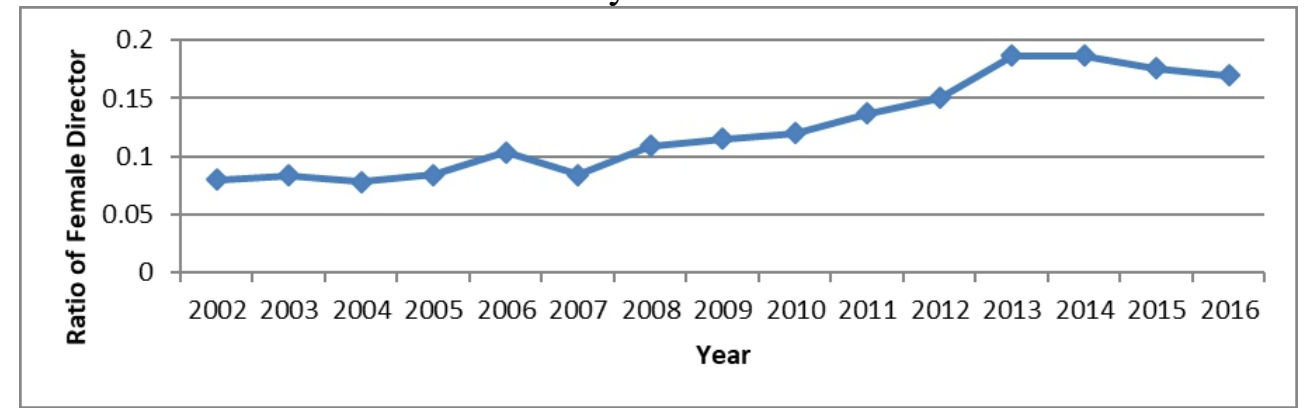

Figure 2: Trend Analysis of Gender Diversity

The results also showed although the change in terms of numbers has been very low, the overall trend in board gender diversity increased across the study period. These findings implied that more women are getting into the board of listed firms as compared with the past. The finding showed most of the listed firms had at least a member who was female on their board. The increase also seems rapid after the inauguration of the new constitution that demands that workplaces should have gender parity. 


\section{Trends Analysis of the Board Occupational Expertise}

This section analyses the board occupational expertise based on the years of experience of the board members. The findings are presented in figure 3.

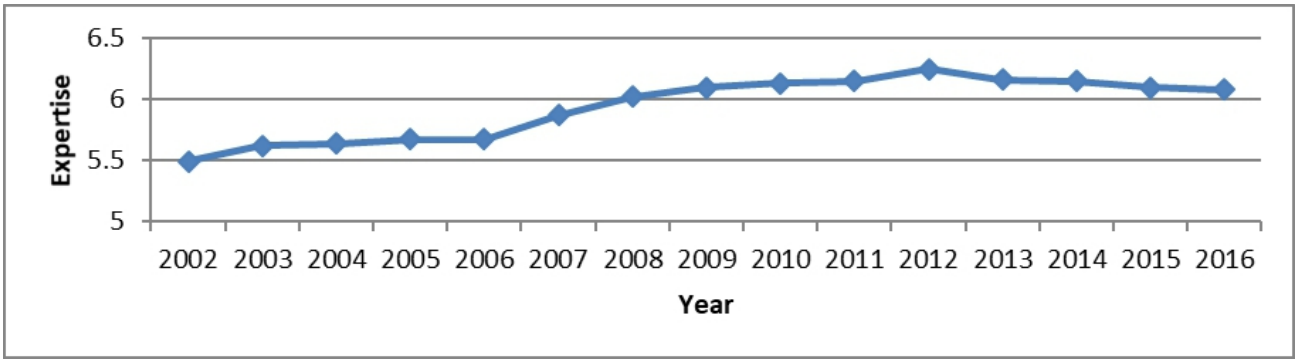

Figure 3: Trend Analysis of Occupational Expertise

The trend analysis presented in figure 3 indicated that occupational experience of the board increased between the years of 2002 and 2016. The findings point to the fact that listed firms in Kenya have been appointing more experienced individuals on their boards. This is in recognition of the critical role played by corporate governance in steering firms to profitability.

\section{Trends Analysis of the Board Age}

The age of board members is also a critical component of board structures that the study sought to analyze. The study sought to establish trend in age of board members among the listed firms in Kenya.

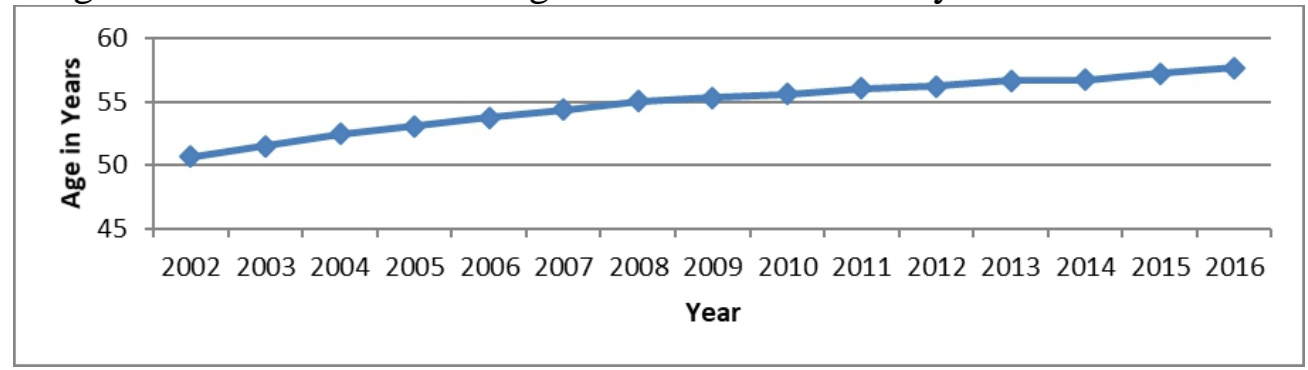

Figure 4: Trend Analysis of Board Age

The results presented in figure 4 showed that there was an increase in the average age of board members of listed firms in Kenya. This increase in the board members' age can be attributed to the fact that members joined the board at a much younger age but grow older while still serving on the board. Similarly, these findings coincide with the findings that the occupational experience also increased during the study period. This indicated a high correlation between age and occupational experience. 


\section{Trends Analysis of the Board Size}

The study also sought to establish the trend in the board size of the listed firms in Kenya. This was done to establish the common practice among the listed firms in terms of board size. The findings are presented in figure 5.

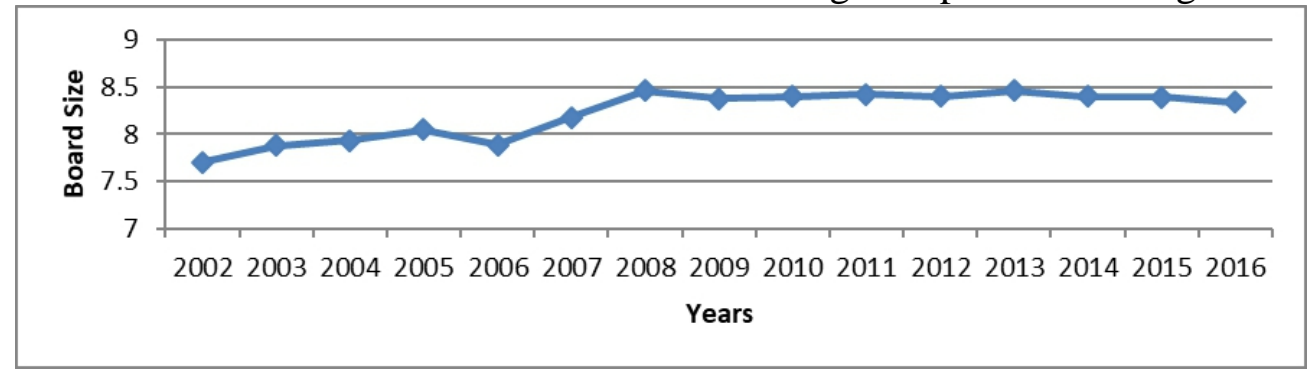

Figure 5: Trend Analysis of Board Size

The results showed that board size increased or grew between 2002 and 2005, in 2006 the average board size dropped slightly from an average of 8 board members to an average of 7 members. The 2007 and 2008 also experienced increase in board size, and then there was no significant change in board size. This implied that on average listed firms maintained their board size between 2008 and 2016. These findings further implied that majority of the listed firms in Kenya have maintained their board size between 8 and 9 members.

\section{Trends Analysis of the ROA}

The study analysed the trends in performance of firms of listed firms in Kenya. The indicators of performance analysed include Return on Assets (ROA) and Tobin's Q.

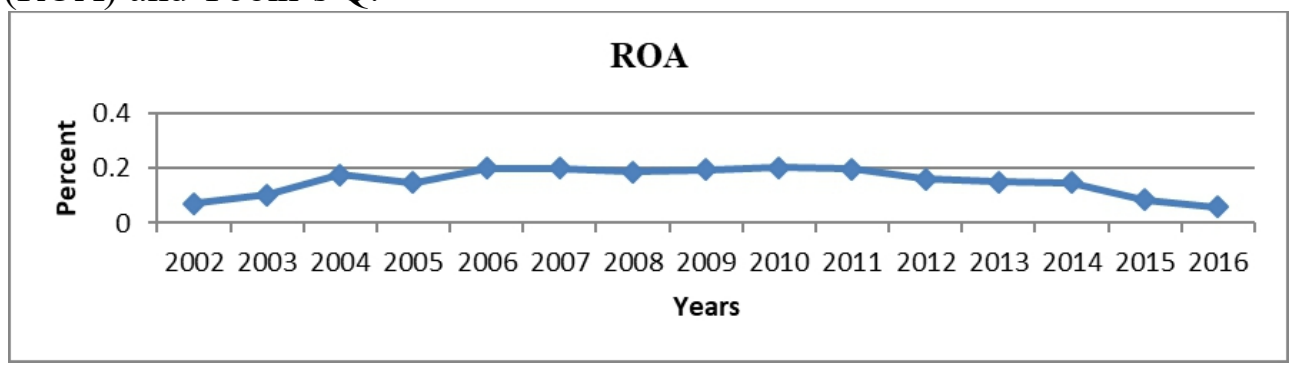

Figure 6: Trends Analysis of the ROA

The trend analysis shows increasing trends in ROA of listed firms between 2002 and 2006. The graph reveals that ROA experienced a small drop in 2008 before stabilizing in 2009, 2010 and 2011. From 2012, ROA of listed firms experienced a significant drop which persisted all the way to 2016. The findings imply that from the 2011 to 2016 listed firms on NSE experienced drop in performance as measured by ROA. These findings are unexpected considering that the corporate governance of listed firms in Kenya has been 
improving as indicated by increased in board independence, board diversity, board size and other aspects of board structures and board activities. These findings could also imply that corporate governance does not significantly enhance the performance of the listed firms in Kenya.

\section{Trends Analysis of the Tobin's $\mathbf{Q}$}

The study also used Tobin's Q to measure the market performance of the listed firms in Kenya. This section presents the trend analysis results on Tobin's Q.

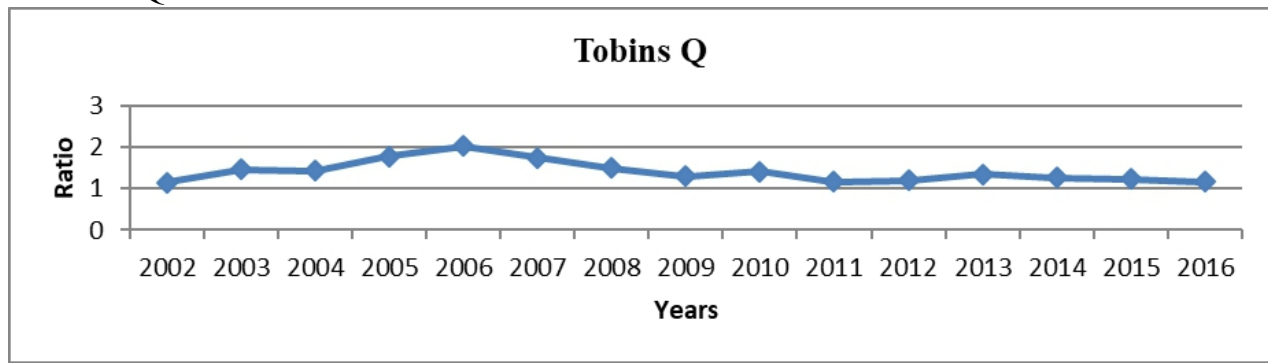

Figure 7: Trends Analysis of the Tobin's Q

Similar to ROA, Tobin's Q of the listed firms in Kenya increased between 2002 and 2006 before experiencing a significant drop between 2006 and 2016. The findings indicate that besides the poor financial performance as shown by ROA, listed firms also recorded poor market performance as shown by the trend analysis of Tobin's Q.

\section{Correlation Analysis}

This section contains the correlation results between the Board Structure Variables and performance of firm.

Table 2: Board Structure Variables and Firm Performance Variables

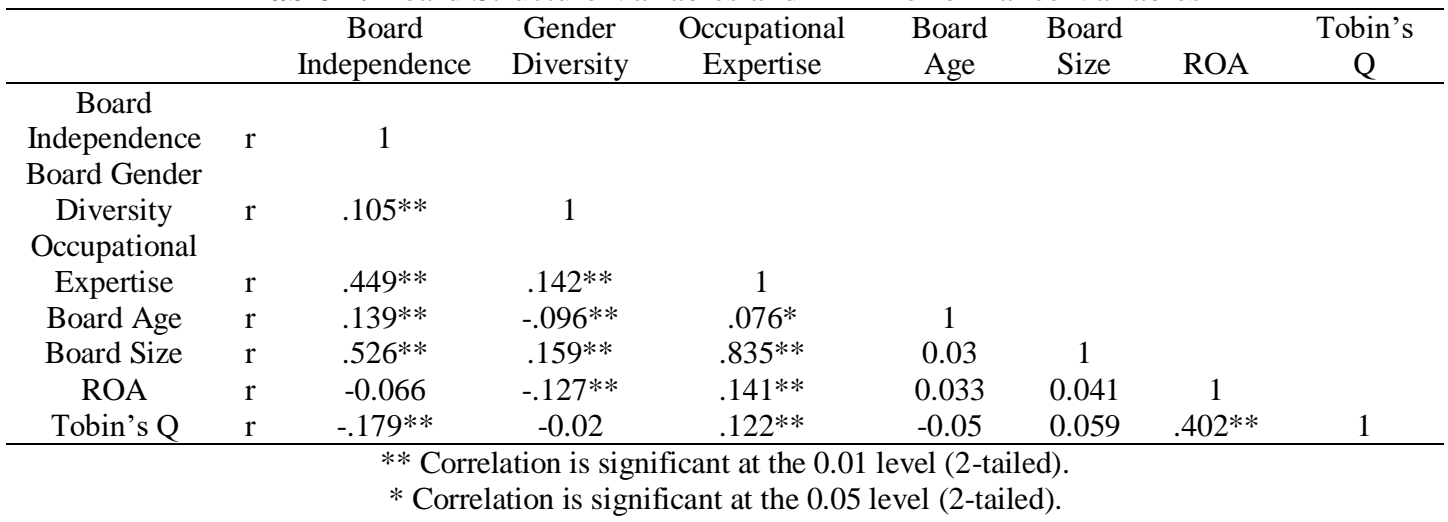

The correlation results revealed that board independence had negative relationship with both ROA and Tobin's Q. However, only the association between board independence and Tobin's Q was weak, negative and 
significant $(\mathrm{r}=-0.179, \mathrm{p}=0.000)$. Board gender diversity had weak, negative association with $\operatorname{ROA}(\mathrm{r}=-0.127, \mathrm{p}=0.000)$ while the association between gender diversity and Tobin's $\mathrm{Q}$ was insignificant. The findings also revealed that board occupational expertise had a weak, positive and significant association with both ROA $(\mathrm{r}=0.141, \mathrm{p}=0.000)$ and Tobin's $\mathrm{Q}(\mathrm{r}=0.122$, $\mathrm{p}=0.000$ ). The finding implied that increasing board occupational expertise would results to increase in both ROA and Tobin's Q. the findings further revealed that board age and size were insignificantly associated to both ROA and Tobin's Q.

\section{Regression Analysis Results}

The study performed tests on statistical assumptions, that is, test of regression assumptions and statistics used. This included test of serial autocorrelation test, panel unit root test, multicollinearity, heteroscedasticity test and Hausman test for model specification to make sure the data used was adequate to conduct inferential analysis. The tests were conducted to make sure that the statistical analysis conducted adhered to regression assumptions hence avoid spurious and bias findings.

\section{Overall Model Fitting}

The results of diagnostics revealed that the data was adequate to fit a regression model. The results of Hausman specification test further revealed that most appropriate model was a regression model; hence the study fitted a random effect model to establish the relationship between Board Structures Variables and performance of firms. Table 4 contains the findings of board structures variables and performance of firms.

Table 3: Random Effect Model Board Structure and Performance of firms

\begin{tabular}{ccccc}
\hline & $\begin{array}{c}\text { Model 1 } \\
\text { ROA }\end{array}$ & \multicolumn{3}{c}{$\begin{array}{c}\text { Model 2 } \\
\text { Tobin's Q }\end{array}$} \\
\hline & Coef. & $\mathbf{P}>|\mathbf{z}|$ & Coef. & $\mathbf{P}>|\mathbf{z}|$ \\
\hline Board Independence & -0.1192 & 0.200 & 0.836 & $\mathbf{0 . 0 1 4}$ \\
Gender Diversity & -0.1494 & $\mathbf{0 . 0 3 8}$ & 0.498 & 0.058 \\
Occupational Expertise & 0.0174 & $\mathbf{0 . 0 3 1}$ & 0.039 & 0.180 \\
Board Age & -0.0016 & 0.384 & 0.018 & $\mathbf{0 . 0 0 6}$ \\
Board Size & -0.0120 & 0.100 & 0.002 & 0.940 \\
_Cons & 0.3396 & 0.005 & 2.882 & 0.000 \\
& & & Wald chi2 $(5)=18.71$ \\
& Wald chi2(5) $=12.96$ & Prob $>$ chi2 $=0.0022$ \\
& Prob > chi2 $=0.0423$ & R-sq: within $=0.0222$ \\
\hline
\end{tabular}

In table 3 , results of Prob $>$ chi2 $=0.0423$ revealed that the overall model was statistically significant which further implied that board structures were significant predictors of ROA. The coefficient results showed that only 
board occupational expertise $(\beta=0.0174, \mathrm{p}=0.031)$ and board gender diversity $(\beta=-0.1494, p=0.038)$ significantly affected ROA. Board gender diversity negatively affected ROA. The results implied that increase in board occupational expertise would results to increase ROA however increase in board gender diversity led to reduction in ROA. Other board structures variable such as board independence $(\beta=-0.1192, p=0.200)$, board size $(\beta=-$ $0.0120, p=0.100)$, and board age $(\beta=-0.0016, p=0.384)$ had insignificant effect on ROA.

Table 3 also presents the RE regression model fitted to test the relationship between board structures and Tobin's Q. The results of Prob $>$ chi $2=0.0022$ revealed that the overall model was statistically significant which implied that board structures were significant predictors of Tobin's Q. The results revealed that board independence $(\beta=-0.836, p=0.014)$ had negative and significant relationship with Tobin's Q. These findings implied that increasing independence led to reduction in Tobin's Q. the results also revealed that board age $(\beta=-0.018, p=0.006)$ had negative and significant effect on Tobin's Q. Similarly, increase in board age led to reduction in Tobin's Q among listed firms in Kenya. The relationship between gender diversity and board size was negative but insignificant. Occupational expertise had a positive and insignificant effect on Tobin's Q among listed firms in Kenya.

\section{Model 1 (ROA) and Model 2 (Tobin's)}

Board Independence and Firm Performance

$\mathrm{FP}_{\text {it }}(\mathrm{ROA})=0.339-0.1192 \mathrm{BI}_{\mathrm{it}}+\mathrm{c}_{\mathrm{i}}+\dot{\varepsilon}_{\text {it }}$

$\mathrm{FP}_{\text {it }}($ Tobin's Q $)=0.2882+0.836 \mathrm{BI}_{\mathrm{it}}+\mathrm{c}_{\mathrm{i}}+\dot{\varepsilon}_{\mathrm{it}}$

Board Diversity and Firm Performance

$\mathrm{FP}_{\text {it }}(\mathrm{ROA})=0.339-0.1494 \mathrm{BD}_{\mathrm{it}}+\mathrm{c}_{\mathrm{i}}+\dot{\varepsilon}_{\mathrm{it}}$

$\mathrm{FP}_{\text {it }}($ Tobin's Q $)=0.2882+0.498 \mathrm{BD}_{\mathrm{it}-1}+\mathrm{c}_{\mathrm{i}}+\dot{\varepsilon}_{\mathrm{it}}$

Board Occupational Expertise and Firm Performance

$\mathrm{FP}_{\mathrm{it}}(\mathrm{ROA})=0.339+0.0174 \mathrm{BE}_{\mathrm{it}-1+\mathrm{c}_{\mathrm{i}}+\dot{\varepsilon}_{\mathrm{it}}}$

$\mathrm{FP}_{\text {it }}\left(\right.$ Tobin's Q) $=0.2882+0.039$ BEit $_{-1}+\mathrm{c}_{\mathrm{i}}+\dot{\varepsilon}_{\mathrm{it}}$

Board Age and Firm Performance

$\mathrm{FP}_{\text {it }}(\mathrm{ROA})=0.339-0.0016 \mathrm{BA}_{\mathrm{it}-1}+\mathrm{c}_{\mathrm{i}}+\dot{\varepsilon}_{\mathrm{it}}$

$\mathrm{FP}_{\text {it }}($ Tobin's $\mathrm{Q})=0.2882+0.018 \mathrm{BA}_{\mathrm{it}-1}+\mathrm{c}_{\mathrm{i}}+\varepsilon_{\mathrm{it}}$

Board Size and Firm Performance

$\mathrm{FP}_{\text {it }}(\mathrm{ROA})=0.339-0.0120 \mathrm{BS} \mathrm{S}_{\mathrm{it}-\mathrm{t}}+\mathrm{c}_{\mathrm{i}}+\dot{\varepsilon}_{\text {it }}$

$\mathrm{FP}_{\text {it }}($ Tobin's $\mathrm{Q})=0.2882+0.002 \mathrm{BS}_{\mathrm{it}-1}+\mathrm{c}_{\mathrm{i}}+\dot{\varepsilon}_{\mathrm{it}}$

Board Structure and Firm Performance

$\mathrm{FP}_{\mathrm{it}}(\mathrm{ROA})=0.339+-0.1192 \mathrm{BI}_{\mathrm{it}}+-0.1494 \mathrm{BD}_{\mathrm{it}-1}+0.0174 \mathrm{BE}_{\mathrm{it}-1}+-$ $0.0016 \mathrm{BA}_{\mathrm{it}-1}+-0.0120 \mathrm{BS}_{\mathrm{it}-1}+\mathrm{c}_{\mathrm{i}}+\dot{\varepsilon}_{\mathrm{it}}$ 
$\mathrm{FP}_{\text {it }}($ Tobin's $\mathrm{Q})=0.2882+0.836 \mathrm{BI}_{\mathrm{it}}+0.498 \mathrm{BD}_{\mathrm{it}-1}+0.039 \mathrm{BE}_{\mathrm{it}-1}+0.018 \mathrm{BA}_{\mathrm{it}-}$ $1+0.002 \mathrm{BS}_{\mathrm{it}-1}+\mathrm{c}_{\mathrm{i}}+\dot{\varepsilon}_{\mathrm{it}}$

Where: $\mathrm{FP}=$ Firm Performance; $\mathrm{BI}_{\mathrm{it}}=$ Board Independence; $\mathrm{BD}_{\mathrm{it}}=$ Board Female Diversity; $\mathrm{BE}_{\mathrm{it}}=$ Board Occupational Expertise; $\mathrm{BA}_{\mathrm{it}}=$ Board Age; $\mathrm{BS}_{\mathrm{it}}=$ Board Size; $\varepsilon=$ Error term.

\section{Summary and Conclusions}

The results of this study revealed an increasing trend in board structures such as board independence, board gender diversity, board occupational expertise, board age and board size of listed firms in Kenya and a decreasing trend of performance measures ROA and Tobin's Q. Results also revealed board occupational expertise and board gender diversity significantly affect ROA, Board gender diversity negatively affected ROA, while board independence, board size, and board age had insignificant effect on ROA. The results further revealed that board independence, board age had negative and significant relationship with Tobin's Q. Gender diversity and board size was negative but insignificant. Occupational expertise had a positive and insignificant effect on Tobin's Q. These results further disclosed different results in the relationship between individual corporate structure variables and firm performance as measured by ROA and Tobin's' Q. The results implied that Board Independence significantly affects firm performance as measured by Tobin's' Q, therefore the study reject the null hypothesis that: $\boldsymbol{H}_{01}$-Board independence does not significantly affect performance of firms listed at the Nairobi Securities Exchange and accept the alternative hypothesis that: $\boldsymbol{H}_{a 1^{-}}$ Board independence significantly affect performance of firms listed at the Nairobi Securities. The results corresponded with those of (Almontaser \& Faudziah, 2018; Maria et al, 2018; Rashid, 2018; Hamdan et al, 2017).

Board gender diversity significantly affects firm performance as measured by ROA, therefore the study reject the null hypothesis that: $\boldsymbol{H}_{02}{ }^{-}$ Board gender diversity does not significantly affect performance of firms listed at the Nairobi Securities Exchange and accept the alternative hypothesis that: $\boldsymbol{H}_{a 2}$-Board gender diversity significantly affect performance of firms listed at the Nairobi Securities. The results also concurred with those of (Geeta et al, 2020; Aqil et al, 2019; Ramzi et al, 2019; Mumba, 2017).

Board occupational expertise significantly affects firm performance as measured by ROA, therefore the study reject the null hypothesis that: $\boldsymbol{H}_{\mathbf{0 3}^{-}}$ Board occupational expertise does not significantly affect performance of firms listed at the Nairobi Securities Exchange and accept the alternative hypothesis that: $\boldsymbol{H}_{a 3}$-Board occupational expertise significantly affect performance of firms listed at the Nairobi Securities. The results coincided with those of (Harjoto et al, 2019; Saidu, 2019; Swarnodeep \& Aurelie, 2019; Arumona et al. 2019). 
Board age significantly affects firm performance as measured by Tobin's' Q, therefore the study reject the null hypothesis that: $\boldsymbol{H}_{04}$-Board age does not significantly affect performance of firms listed at the Nairobi Securities Exchange and accept the alternative hypothesis that: $\boldsymbol{H}_{a 4}$-Board age significantly affect performance of firms listed at the Nairobi Securities. The results agreed with those of (Danoshana \& Ravivathani, 2019; Ilhan et al, 2019; Rekha \& Husam-Aldin, 2017).

Board size insignificantly affects firm performance as measured by both ROA and Tobin's' Q, therefore the study accepts the null hypothesis that: $\boldsymbol{H}_{05}$-Board size does not significantly affect performance of firms listed at the Nairobi Securities Exchange. The results also concurred with those of (Danoshana \& Ravivathani, 2019; Ilhan et al, 2019; Rekha \& Husam-Aldin, 2017).

These results finally implied that overall board structure significantly affect performance of listed firms at the Nairobi Securities Exchange as measured by both ROA and Tobin's. Therefore the study reject the null hypothesis that: $\boldsymbol{H}_{06}$-Board structure not significantly affect performance of firms listed at the Nairobi Securities Exchange and accept the alternative hypothesis that: $\boldsymbol{H}_{a 6}$-Board structure significantly affect performance of firms listed at the Nairobi Securities Exchange. The results lastly matched those of (Kobuthi et al, 2018; Jordi et al, 2018; Suganya \& Kengatharama, 2017). The study established that most of the board structure practices adopted by listed firms in Kenya have significant effect of the performance of listed firms. The study also found that listed firms in Kenya strengthened their board structure practices due to poor performance; and further concluded that board structure has overall positive effect on performance of listed firms.

\section{Recommendations}

Based on the findings that board structure and board structure variables affect performance of firms except board size, shareholders and other stakeholders should emphasise on proper structuring of the board taking into consideration of these variables to enhance performance of firms. Kenyan corporate governance regulating authorities such as Capital Market Authority, Central Bank of Kenya and Insurance Authority of Kenya and Manufacturing Authority of Kenya should develop specific policies on board structure variables to guide firms on how to structure their boards to achieve higher performance. Regulatory authorities should further review the board structure principles of listed firms to make them to pragmatic and to ensure shareholders' interests are protected.

There is a need for further research in this area. The study used two measures of performance, however a part from overall result, where board structure affect performance, for individual variables none, has given 
significant effect on both ROA and Tobin's' Q. Board has given insignificant effect measured by both ROA and Tobin's which contradicts some empirical results. Further studies in different context and methodologies may generate more knowledge to this area which has remained controversial for a long time.

There is a need for the Kenyan government to develop common corporate governance policy for all firms. Currently there are different corporate governance principles from different regulators making difficult for firms to adhere to all the requirements. Most firms are trying to meet the regulations requirements for conformity rather than to enhance performance of firms to achieve stakeholders' returns.

\section{References:}

1. Agrawal, A. \& Knoeber, C.R. (1996). Firm performance and mechanisms to control agency problems between managers and shareholders. Journal of Financial and Quantitative Analysis 31, $377-$ 397.

2. Akisimire, R., Masoud, M. S., Baisi, M.D. \& Orobia,L., A. (2016). Board member age diversity and financial performance of manufacturing firms: a developing economy perspective, Journal of Economics and Behavioural Studies. 8(5), 120-132.

3. Almontaser, A., M., Q. \& Faudziah, H., F. (2018). The Effect of Board Independence and board meeting on firm performance: Evidence from Jordan. Journal of Finance and Accounting. 6(5), 105-109.

4. Aluoch, M.O., Kaijage, S.K., Iraya, C, M, \& Ogutu, M. (2019). Corporate governance, financial characteristics, macroeconomic factors and performance of commercial and services the Nairobi Securities Exchange. International Journal of Business and Social Science, 10(2), 12-26.

5. Aqil Waqar Khan \& Qazi Abdul Subhan | Collins G. Ntim (Reviewing editor) (2019) Impact of board diversity and audit on firm performance, Cogent Business \& Management, 6(1), DOI: $10.1080 / 23311975.2019 .1611719$

6. Arumona, J., Erin, O., Onmonya, L. \& Omotayo, V. (2019). Board financial education and firm performance: evidence from the healthcare sector in Nigeria, Academy of Strategic Management Journal, 18(4), 1-14.

7. Carpenter, M., Geletkanycz, M. \& Sanders, W. (2004). Upper echelons research revisited: Antecedents, elements, and consequences of top management team composition. Journal of Management, 30(6), 747778. 
8. Carroll, E. (2018). How Director Age Influences Corporate Performance, Equilar, Inc., on Thursday, January 4, 2018, Harvard Law School Forum on Corporate Governance.

9. Danoshana S, \& Ravivathani T. (2019). The impact of the corporate governance on firm performance: A study on financial institutions in Sri Lanka, SAARJ Journal on Banking \& Insurance Research, 8(1), 62-67.

10. Fama, E. F. \& Jensen, M. C. (1983). Separation of Ownership and Control, Journal of Law and Economics, 26(2), 301-325.

11. Fama, E. F. (1980). Agency problems and the theory of the firm. Journal of Political Economy, 88(2), 288-307.

12. Geeta, D., Narendar V. R., Neha, M., Frank, S. \& Debasis, P. (2020). Gender diversity and firm performance: evidence from India and Singapore, Applied Economics, 52(14), 1553-1565,

DOI: $10.1080 / 00036846.2019 .1676872$

13. Hamdan, A.M.M. \& Al Mubarak, M.M.S. (2017). The impact of board independence on accounting-based performance: Evidence from Saudi Arabia and Bahrain, Journal of Economic and Administrative Sciences, 33(2), 114-130.

14. Harjoto, M.A., Laksmana, I. \& Yang, Y.W. (2019). Board nationality and educational background diversity and corporate social performance, Corporate Governance, 19(2), 217-239.

https://doi.org/10.1108/CG-04-2018-0138.

15. Hawley, J.P. \& Williams, A.T. (1996) Corporate governance in the United States: The rise of fiduciary Capitalism". Working Paper, Saint Mary's College of California, School of Economics and Business Administration.

16. Hillman, A.J., Canella, A. A. \& Paetzold, R. L. (2000). The resource dependency role of corporate directors: strategic adaptation of board composition in response to environmental change. Journal of Management Studies, 37(2), 235-255.

17. Ilhan, T., Ekrem, W., Geoffrey, Mehmet, D. \& Selim, Z., (2019). Corporate governance and firm performance in emerging markets: Evidence from Turkey, International Business Review, 28(1), 90-103.

18. Jensen, M.C. \& Meckling, W. (1976).Theory of the firm: managerial behaviour, agency costs, and capital structure. Journal of Financial Economics 3, 305-360.

19. Jeyan, S.S. \& Lingesiya, K. (2017). Board structure and financial performance of listed finance companies in Sri Lanka, International Journal of Accounting and Financial Reporting, 7(2), 292-302. 
20. Jordi, P., Rafael, R. \& Juan, S. (2018). Corporate governance and financial performance: The role of ownership and board structure, Journal of Business Research, 89, 229-234.

21. Kamau, G., Machuki, V. \& Aosa, E. (2018). Corporate Governance and Performance of Financial Institutions in Kenya. Academy of Strategic Management Journal,17(1), 1-13.

22. Khanchel, I. (2007). Corporate governance: measurement and determinant analysis. Managerial Auditing Journal, 22 (8), 740-760.

23. Kobuthi, E., K'Obonyo, P. \& Ogutu, M. (2018). Corporate governance and performance of firms listed on the Nairobi Securities Exchange, International Journal of Scientific Research and Management, 6(1), 2321-3418.

24. María, V. B., Jennifer, M.F. \& Isabel, M. S. (2018). Board independence and firm performance: The moderating effect of institutional context, Journal of Business Research, 88,28-43.

25. Mumba, B. (2017). Board gender diversity and firm performance: An empirical analysis of panel data from companies listed on the Lusaka stock exchange (November 2, 2017). Available at SSRN:

https://ssrn.com/abstract $=3061877$ or http://dx.doi.org/10.2139/ssrn.3061877

26. Murby, L. and Gould, S. (2005). Effective Performance Management with the Balanced Scorecard. The Chartered Institute of Management Accounting (CIMA) Research Report. Accessed from: www.cimagloabal.com/technicalreports on 23rd March, 2018

27. Nermeen, S., Ahmed, S. \& Moataz, E. (2017). Board diversity and firm performance: evidence from the U.K. SMEs, Applied Economics, 49(48), 4817-4832,

DOI: $10.1080 / 00036846.2017 .1293796$

28. Nisar, A., Amjad, N. \& Amna, F. (2018). An empirical analysis of boardroom diversity on firm performance, Review of Economics \& Finance, 13(3), 62-76.

29. Omware, I., M., Atheru, G. \& Jagongo, A. (2020). Corporate governance and financial performance of selected commercial banks listed at Nairobi Securities Exchange in Kenya, International Academic Journal of Economics and Finance, 3(5), 75-91.

30. Pfeffer, J. \& Salancik, G. R. (1978), The External Control of Organizations: A Resource Dependence Perspective, Harper \& Row, New York.

31. Pound, J. (1992). Beyond takeovers: politics comes to corporate control, Harvard Business Review, 70, (2), 83-93.

32. Rashid, A. (2018). Board independence and firm performance: Evidence from Bangladesh, Future Business Journal, 4, 34-49. 
33. Rekha, P., \& Husam-Aldin, N. (2017). Relationship between corporate governance and firm performance: Evidence from GCC countries, Research in International Business and Finance, 44, 394-410.

34. Rose, C. (2007). Does female board representation influence firm performance? The Danish evidence, corporate governance. An International Review, 15(2), 404-413.

35. Saidu, S. (2019). CEO characteristics and firm performance: focus on origin, education and ownership. Journal of Global Entrepreneurship Research, 9(29), 1-15.

36. Saseela, B. (2018). Corporate Governance and Firm Performance: Empirical Evidence from Emerging Market, Asian Economic and Financial Review, 8(12), 1415-1421.

37. Swarnodeep, H. \& Aurelie, S. (2019). Do board expertise and networked boards affect environmental performance? Journal of Business Ethics, 158, 269-292.

Thursday, January 4, 2018, Harvard Law School Forum on Corporate Governance.

38. Williamson, O. E. (1996). The Mechanisms of Governance. Oxford University Press, Oxford. 